\title{
The Influence of Accounting Measurement on the Stock Price: Emerging Market Evidence
}

\author{
Mohammed ALASHI \\ Faculty of Economics and Administrative Sciences, \\ Islamic University of Gaza, P.O. Box 108, Gaza, Palestine \\ malashi@iugaza.edu.ps
}

\begin{abstract}
The study examines the effect of accounting measurements that includes: earning per share, current ratio, debt to equity ratio, and cash flow ratio on the stock price of manufacturing companies listed in Palestine exchange. According to the information availability; the researcher selected 10 companies out of 13 to be examined. The period from 2015 to 2020 is covered by the study. Panel data is used to apply the least square regression model. The study revealed that there is no significant effect of EPS, Current ratio, Debit to Equity, Cash flow Ratio on the stock prices of manufacturing sector companies listed in the Palestine Exchange from 2015 to2020.
\end{abstract}

Keywords: stock prices, earning per share, current ratio, debt to equity ratio, cash flow ratio

DOI: $10.7176 /$ RJFA/13-4-05

Publication date: February $28^{\text {th }} 2022$

\section{Introduction}

Rational investors look forward to maximize the wealth, regardless of the investment type. All the time, investors try to find out the best approach to analyze cost, benefit, and risk of investment portfolio. In the stock markets, there are many factors influence the direction of the decisions Mainly its macro-economic factors such as exchange rate, oil price, politician risk, GDP, gold price, etc. (Abed Qader, 2017; Bagh et al., 2017; Baranidharan \& Alex, n.d.; Bernal-Ponce et al., 2020; Sheikh et al., 2020; Singhal et al., 2019; Siregar \& Diana, 2019).

In the same line, micro economic factors that influence the investment decision making are: profitability, debt, dividends, the firm growth, etc. (Arbidane \& Volkova, n.d.; Bustani et al., 2021; Husain et al., 2020; Husna \& Satria, 2019; Öztürk, 2017). Referring to signaling theory, many researchers confirm that the debt to equity ratio (DER), return on assets (ROA), return on equity (ROE), earnings per share (EPS) and other accounting measurements affect the investment decisions reflected on the stock price (Imran, 2018; Siregar \& Doriawaty, 2021; Utami \& Darmawan, 2019).

\section{Problem statement}

Many researchers measure the relationship and the impact between the accounting ratios and the stock price. Basu (1977) one of the earliest scholars measures the relationship between earnings ratio and the stock price. In the same line Fama \& French (1988) have suggested that accounting ratios are an essential approach for understanding the stock market performance. Later on, many researches investigate the impact of accounting ratios on the stock price in different regions and different periods such as Ayadi \& Pyun, 1994; Bustani et al., 2021; Husain et al., 2020; Husna \& Satria, 2019; Kamar, 2017; Siregar \& Doriawaty, 2021). However, the existence of contradictory research results seams a real problem that necessitates conducting further research. For instance, as mentioned in the literature review, some researchers concluded that the probability ratio, debt ratio, liquidity, etc. impact the stock price while others concluded they do not. Based on the above described background, the research main question is: what is the impact of accounting measurements on the stock price? The sub questions are the following:

1. What is the impact of earnings per share (EPS) on the stock price?

2. What is the impact of Current Ratio on the stock price?

3. What is the impact of Debt to Equity ratio on the stock price?

4. What is the impact of Cash Flow Ratio on the stock price?

\section{Literature review}

To predict the stock price, many researchers use a verity of accounting measurements such as Earning per Share, Price to Book Value, Return of Equity, Current Ratio, Debt to Equity, and Percentage Changes of Net Sales. They use annual data from 2011-2015 and cover 109 listed non-financial firms of Pakistan's Stock Exchange (PSX) (Imran, 2018). They also use Return on Equity (ROE) and Debt to Equity Ratio (DER) on stock price to analyze cement industry listed in Indonesia Stock Exchange totaling 3 cement companies from 2011 until 2015 (Kamar, 2017). Astuty (2017), on another hand, uses price earnings ratio, earning per share, net profit margin, price to book value and systematic risk to analyze companies registered in LQ45 Index in the period 2011-2015. In Indonesia Stock Exchange during the period 2012-2016, scholars analyze the return on equity, earnings per share, and total assets turn over (Asmirantho \& Somantri, 2017). To measure food and beverage companies of five years (2014- 
2018), Bustani et al. select a sample of 12 companies from 26 companies in the population of food and beverage companies that have met the criteria and analyze earning Per Share (EPS), Price to Book Value (PBV), Dividend Payout Ratio (DPR), and Net Profit Margin (NPM) (2021). At Belgrade Stock Exchange, 42 companies that represent the composition of the BelexLine index for the period from 2010 to 2014 are selected to analyze return on assets, return on equity, earnings per stock, book value, price-earnings ratio, price-to-book ratio and leverage (Milosevic-Avdalovic \& Milenkovic, 2017). Musallam, (2018) selects 26 Qatari listed firms from 2009 to 2015 to analyze earnings per share, earnings yield ratio, and dividend yield ratio. Finally, at Istanbul Stock Exchange over the period 2008-2016 Öztürk analyzes current ratio, earnings to price, net profit margin and stock return (2017). As it has been mentioned above, researchers examine different accounting measurements to predict the stock price. It's worth to clarify and insist that many variables and not uniform are adopted by the researchers to analyze or predict the stock price.

To measure the effect, the researchers use diverse approaches such as logistic regression model (Imran, 2018), Ordinary Least Square (OLS) method (Kamar, 2017), regression analysis of panel data, $t$ test, F test, and classical assumption of normality, multicollinearity, heteroscedasticity and autocorrelation tests (Asmirantho \& Somantri, 2017), boostraping in the Structural Equation Modelling-Partial Least Square (SEM-PLS) (Bustani et al., 2021), Common Effect, Fixed Effect, and Random Effect. Chow test model, Hausman test, and Lagrange Multiplier test (Herawati \& Angger, 2018; Siregar \& Doriawaty, 2021), Weighted Least Square (WLS) (Musallam, 2018), VAR methodology (Meriç et al., 2017), a multiple regression analysis (Husna \& Satria, 2019; and Karamoy \& Tulung, 2020).

In different studies, researchers have shown Positive impact results, such as Imran, (2018) who states that accounting ratios significantly predict the stock performance. In addition, Astuty (2017) points out that there is a significant influence between the Price Earnings Ratio (PER), Earning per Share (EPS), Net Profit Margin (NPM), Price to Book Value (PBV), and Risk Systematic on stock prices. Moreover, Asmirantho \& Somantri, (2017) conclude that EPS has positive and significant influence to stock price. Similarly, Bustani et al. (2021) reveal significant effect of Earning per Share, Price to Book Value, and Dividend Payout Ratio on stock prices. Furthermore, Utami \& Darmawan, (2019) state that earning per share and market value added have a positive effect on stock prices, while Siregar \& Doriawaty point out that Return On Equity had a positive and partially significant effect on Stock Prices (2021). Positive effect is also clear in Milosevic-Avdalovic \& Milenkovic, (2017) who declare that the size of the company measured by assets, return on assets, leverage, earnings per stock, book value and price-to-book ratio provide a unique contribution to a statistically significant predictor of stock prices. More positive results are declared by Musallam (2018) who concludes that earnings per share, earnings yield ratio, and dividend yield ratio have significant and positive relationship with market stock returns. Then, Jermsittiparsert et al. (2019) conclude that current ratio, quick ratio, assets growth, return on assets, return on equity, return on capital employed, and price to earnings ratio are significant determinants of stock price. Finally, earnings to price and net profit margin are revealed to be significant in explaining stock returns in Istanbul Stock Exchange (Öztürk, 2017).

Contrary to the previous studies that reveal a negative or no impact, many other studies reveal positive or insignificant impact such as Kamar (2017) who finds out that Equity (ROE) has significant effect on the stock price, while the effect of Debt to Equity Ratio (DER) is not significant. Similarly, Asmirantho \& Somantri (2017) discover that the ROE has no effect but positive on the stock price. In addition, Bustani et al. (2021) point out that the Net Profit Margin does not significantly affect stock prices. Moreover, Utami \& Darmawan (2019) conclude that debt to equity ratio, return on assets and return on equity partially have no effect on stock prices. Furthermore, Earning Per Share variables are said to have a negative and significant effect partially on Stock Prices (Siregar \& Doriawaty, 2021). liquidity and profitability have no significant effect on firm value (Sinaga \& Malau, n.d.), while market to book value ratio, return on assets, return on equity, price to earnings ratio, dividends earnings ratio, and net profit margin have insignificant relationship with market stock returns (Musallam, 2018). ROA, too, has a positive but non-significant influence on the stock price (Karamoy \& Tulung, 2020), and finally, current ratio is found insignificant (Öztürk, 2017).

\section{Methodology}

In this section, the researcher is going to shed light on the study design, data collection, the type of statistical tests used, sample and population, and finally, the study variables.

Data: raw data; stock price, earnings per share, current ratio, debit to equity ratio, and cash flow ratio are collected from the official Palestine exchange website www.pex.ps.

Test: A quantitative method is adopted; panel data by least square method is applied to measure the impact of the earnings per share, current ratio, debit to equity ratio, and cash flow ratio on the difference of stock prices.

Periods: the collected data covers the period from 2015 to 2020.

Population: The population of the study includes all 13 industrial companies listed at Palestine exchange, but only 10 companies' data are used to be analyzed according to information availability. 
Model: The dependent variable (Y) was the firm stock price of the forward year, and the independent variables are: $x_{1}=$ EPS, $x_{2}=$ Current Ratio, $x_{3}=$ Debit/ Equity, $x_{4}=$ Cash Flow Ratio. The regression equation is as the following:

$$
\begin{gathered}
\mathrm{D}(\mathrm{STOCK})=1.98-3.014 * \mathrm{EPS}-0.0175 * \mathrm{CURRENTRATIO}-2.0157 * \text { DEBITEQUITY }+ \\
0.01871 * \mathrm{CASHFLOWRATIO}+[\mathrm{CX}=\mathrm{F}, \mathrm{PER}=\mathrm{F}](1)
\end{gathered}
$$

\section{Statistical analysis and results}

The following section presents the analysis of the data; it includes the test of regression model's assumption, and then the regression analysis results.

\subsection{Model relevancy}

The regression's pre-assumption test is presented as follows:

1. Normality test: according to Gujarati (2015), the Central Limit Theory states that the sample has normal distribution when it is greater than 30 observations $(n>30)$. Since the population of the present study is 60 observations it is acceptable to suppose the normality of the data distribution.

2. Multi-collinearity test: variance inflation factor is calculated to test the multi-collinearity between the independent variables, as shown in the table below

Table 1: Independent variables VIF

\begin{tabular}{|l|l|c|}
\hline$\#$ & \multicolumn{1}{|c|}{ Independent variable } & VIF \\
\hline 1 & Earnings per share & 1.12 \\
\hline 2 & Current ratio & 1.12 \\
\hline 3 & Debit to equity & 22.16 \\
\hline 4 & Cash flow ratio & 22.46 \\
\hline
\end{tabular}

As shown in table (1), the VIF of debt to equity and cash flow ratio is greater than 10 , so both have to be eliminated from the regression model.

3. It is confirmed that the data has no autocorrelation problem. By performing the Durbin-Watson test through comparing the value of (DW) with the tabular values of (dl;du) based on sample size (n) and the number of variables $(\mathrm{k})$, the existence of the autocorrelation problem is rejected if the value of DW falls in the range $(\mathrm{du} ; 4-\mathrm{du})($ Gujarati, 2015). The calculated $(\mathrm{DW})$ value was $=(2.24)$. From the table of critical values for the $(\mathrm{DW})$ test at $(\mathrm{k}=4)$ and $(\mathrm{n}=60)$, the critical values were $(\mathrm{dl}=1.317)$ and $(\mathrm{du}=1.520)$. This means that there is no autocorrelation problem because the DW value is in the range $(1.520 ; 2.48)$.

4. For Panel Data, there are three models to be preferred in aim of estimating the appropriate model for the study:
a) Pooled Regression Model.
b) Fixed Effect Model; and
c) Random Effect Model.

To determine the best model, the Lagrange Multiplier (Breusch-Pagan) test was used to choose between a pooled regression model and a random effects model. The Hausman Test was also used in order to choose between the random effects model and the fixed effects model. According to the analysis, the fixed effects model is the appropriate one.

\subsection{Regression model results}

Table (2) presents the regression model results. As mentioned above, the data is normally distributed. The multicollinearity is solved by eliminating debit to equity and cash flow ratio. Auto correlation does not exist among the variables. The panel data analysis shows that $\mathrm{R}$ square is $7 \%$ and the probability (F statistics) is 0.286 . This means that the least square regression model is significant to determine the impact of EPS and current ratio on the stock price of the manufacturing companies listed at Palestine exchange.

Table 2: regression model results

\begin{tabular}{|l|c|c|c|}
\hline \multicolumn{1}{|c|}{ Variable } & Coefficient & T - statistic & Sig \\
\hline C & 1.156 & 2.600 & 0.0137 \\
\hline Eps & -3.399 & -2.096 & 0.0436 \\
\hline Current Ratio & -.00056 & -0.432 & 0.6688 \\
\hline R & \multicolumn{3}{|c|}{0.355} \\
\hline R squared & \multicolumn{3}{|c|}{0.070} \\
\hline F-statistic & \multicolumn{3}{|}{0.247} \\
\hline Prob. (F-statistic) & \multicolumn{3}{|}{2.164} \\
\hline Durbin Watson stat & \multicolumn{3}{|}{} \\
\hline
\end{tabular}




\section{Conclusion}

Based on the results of the study, there is no significant effect of EPS, Current ratio, Debit to Equity, Cash flow Ratio on the stock prices of manufacturing companies listed in the Palestine Exchange in 2015-2020. It is worth to mention that many research studies in this area have revealed similar results (Asmirantho \& Somantri, 2017; Bustani et al., 2021; Kamar, 2017; Musallam, 2018; Siregar \& Doriawaty, 2021). Consequently, the researcher believes that there is a need to conduct more investigation to reveal the investor's behavior.

\section{Recommendations}

Based on the results of the present research and the conclusions stated above, further research is needed to insert and examine other variables to investigate the effect on the stock price with extended study periods.

\section{References}

Abed Qader, B. (2017). Measure the impact of exchange rates fluctuations and stock market returns volatility by GARCH model. The Arabic Journal of Human and Social Sciences. Retrieved from https://www.asjp.cerist.dz/en/downArticle/

Arbidane, I., \& Volkova, J. (n.d.). External factors influencing management of company's current assets: Management theory and studies for rural business an infrastructure development. Scientific Journal, 34 (5), 7.

Asmirantho, E., \& Somantri, O. K. (2017). The effect of financial performance on stock price at pharmaceutical sub-sector company listed in Indonesia stock exchange. JIAFE. Jurnal Ilmiah Akuntansi Fakultas Ekonomi, 3(2), 94-107. Retrieved from https://doi.org/10.34204/jiafe.v3i2.778

Astuty, P. (2017). The Influence of fundamental factors and systematic risk to stock prices on companies listed in the Indonesian Stock Exchange. European research studies journal, XX(4A), 230-240. Retrieved from https://doi.org/10.35808/ersj/830

Ayadi, O. F., \& Pyun, C. S. (1994). An application of variance ratio test to the Korean securities market. Journal of Banking \& Finance, 18(4), 643-658.

Bagh, T., Azad, T., Razzaq, S., Liaqat, I., \& Khan, M. A. (2017). The Impact of exchange rate volatility on stock index: Evidence from Pakistan Stock Exchange (PSX). International Journal of Academic Research in Accounting, Finance and Management Sciences, 7(3), 70-86. Retrieved from https://doi.org/10.6007/ IJARAFMS/v7-i3/3150

Baranidharan, S., \& Alex, A. (n.d.). Volatility spillover of exchange rate on stock market evidence from South Africa. Asian Journal of economics, Finance, and Management, 2(3), 26 - 34.

Basu, S. (1977). Investment performance of common stocks in relation to their price - earnings ratios: A test of the efficient market hypothesis. The Journal of Finance, 32(3), 663-682.

Bernal-Ponce, L. A., Castillo-Ramírez, C. E., \& Venegas-Martínez, F. (2020). Impact of exchange rate derivatives on stocks in emerging markets. Journal of Business Economics and Management, 21(2), 610-626. Retrieve from https://doi.org/10.3846/jbem.2020.12220

Bustani, B., Kurniaty, K., \& Widyanti, R. (2021). The effect of earning per share, price to book value, dividend payout ratio, and net profit margin on the stock price in Indonesia Stock Exchange. Jurnal Maksipreneur: Manajemen, Koperasi, Dan Entrepreneurship, 11(1). Retrieved from https://doi.org/10.30588/jmp.v11i1.810

Fama, E. F., \& French, K. R. (1988). Permanent and temporary components of stock prices. Journal of Political Economy, 96(2), 246-273. Retrieved from https://doi.org/10.1086/261535

Gujarati, D. N. (2015). Econometrics by Example. (2nd. Ed.). Palgrave: Macmillan.

Herawati, A. \& Angger. (2018). The Influence of fundamental analysis on stock prices: The Case of food and beverage industries. European research studies journal, XXI(3), 316-326. Retrieved from https://doi.org/10.35808/ersj/1063

Husain, T., Sarwani, Sunardi, N., \& Lisdawati. (2020). Firm's value prediction based on profitability ratios and dividend policy. Finance \& Economics Review, 2(2), 13-26. Retrieved from https://doi.org/10.38157/finance-economics-review.v2i2.102

Husna, A., \& Satria, I. (2019). Effects of return on asset, debt to asset ratio, current ratio, firm size, and dividend payout ratio on firm value. International Journal of Economics and Financial Issues, 9(5), 50-54. Retrieved from https://doi.org/10.32479/ijefi.8595

Imran, K. (2018). Prediction of stock performance by using logistic regression model: Evidence from Pakistan Stock Exchange (PSX). Asian Journal of Empirical Research, 8(7), 247-258. Retrieved from https://doi.org/10.18488/journal. 1007/2018.8.7/1007.7.247.258

Jermsittiparsert, K., Ambarita, D. E., Mihardjo, L. W., \& Ghani, E. K. (2019). Risk-return through financial ratios as determinants of stock price: A Study from Asian region. Journal of Security and Sustainability Issues, 9(1), 199-210. Retrieved from https://doi.org/10.9770/jssi.2019.9.1(15)

Kamar, K. (2017). Analysis of the effect of return on equity (Roe) and debt to equity ratio (Der) of stock price on 
cement industry listed in Indonesia Stock Exchange (Idx) in the year of 2011-2015. IOSR Journal of Business and Management, 19(05), 66-76. Retrieved from https://doi.org/10.9790/487X-1905036676

Karamoy, H., \& Tulung, J. E. (2020). The effect of financial performance and corporate governance to stock price in non-bank financial industry. Corporate Ownership and Control, 17(2), 97-103. Retrieved from https://doi.org/10.22495/cocv17i2art9

Meriç, E., Kamışlı, M., \& Temizel, F. (2017). Interactions among stock price and financial ratios: The case of Turkish banking sector. Applied Economics and Finance, 4(6), 107. Retrieved from https://doi.org/10.11114/aef.v4i6.2755

Milosevic-Avdalovic, S., \& Milenkovic, I. (2017). Impact of company performances on the stock price: An empirical analysis on select companies in Serbia. Ekonomika Poljoprivrede, 64(2), 561-570. Retrieved from https://doi.org/10.5937/ekoPolj1702561M

Musallam, S. (2018). Exploring the relationship between financial ratios and market stock returns. Eurasian Journal of Business and Economics, 11(21), 101-116. Retrieved from https://doi.org/10.17015/ejbe.2018.021.06

Öztürk, H. (2017). The Relationship between earnings-to-price, current ratio, profit margin and return: An Empirical analysis on Istanbul Stock Exchange. Accounting and Finance Research, 7(1), 109. Retrieved from https://doi.org/10.5430/afr.v7n1p109

Sheikh, U. A., Asad, M., Ahmed, Z., \& Mukhtar, U. (2020). Asymmetrical relationship between oil prices, gold prices, exchange rate, and stock prices during global financial crisis 2008: Evidence from Pakistan. Cogent Economics \& Finance, 8(1), 1757802. Retrieved from https://doi.org/10.1080/23322039.2020.1757802

Sinaga, J. A., \& Malau, H. (n.d.). The effect of liquidity and profitability on company value: A Study on consumer goods industry sector companies in the food and beverage sub-sector on the IDX in 2018 - 2019. Journal Economis, 13(3). Retrieved from https://jurnal.unai.edu/index.php/jeko/article/view/2395

Singhal, S., Choudhary, S., \& Biswal, P. C. (2019). Return and volatility linkages among international crude oil price, gold price, exchange rate and stock markets: Evidence from Mexico. Resources Policy, 60, $255-261$. Retrieved from https://doi.org/10.1016/j.resourpol.2019.01.004

Siregar, E. I., \&. Diana. (2019). The impact of political risk and macroeconomics on stock return at Indonesia Stock Exchange: An Approach of Arbritage Pricing Theory (APT)). International Conference on Economics, Management, and Accounting (ICEMA)/ Pages 744-772. Retrieved from https://doi.org/10.18502/ kss.v3i26.5412

Siregar, O., \& Doriawaty, R. (2021). The effect of financial ratios on stock prices in food and beverage companies on IDX. Accounting and Business Journal, 3(2), 155-164. Retrieved from https://doi.org/10.54248/abj.v3i2.4014

Utami, M. R., \& Darmawan, A. (2019). Effect of DER, ROA, ROE, EPS and MVA on stock prices in Sharia Indonesian Stock Index. Journal of Applied Accounting and Taxation, 4(1), 15-22. Retrieved from https://doi.org/10.30871/jaat.v4i1.1195 